Secretariat (SEGIB), Inter-American Development Bank, InterAmerican Institute for Cooperation on Agriculture (IICA), Italy, Japan, South Korea, Latin American Economic System (SELA), Nicaragua, Organization of American States (OAS), Pan American Health Organization/World Health Organization (PAHO/WHO), Pakistan, Portugal, Romania, Russia, San Marino, Spain, Switzerland, Ukraine, UN Development Programme, UN Economic Commission for Latin America and the Caribbean (ECLAC).

Official languages: Portuguese and Spanish.

Headquarters: Calle Cebollatí 1461, Barrio Palermo,

Casilla de Correos 20005, 11200 Montevideo, Uruguay.

Website: http://www.aladi.org

Email: sgaladi@aladi.org

Secretary-General: Carlos Álvarez (Argentina).

\section{Latin American Reserve Fund}

Established in 1991 as successor to the Andean Reserve Fund, the Latin American Reserve Fund assists in correcting payment imbalances through loans with terms of up to four years and guarantees extended to members, to co-ordinate their monetary, exchange and financial policies and to promote the liberalization of trade and payments in the Andean sub-region.

Members. Bolivia, Colombia, Costa Rica, Ecuador, Paraguay, Peru, Uruguay, Venezuela.

Official language: Spanish.

Headquarters: Avenida 82, №12-18, piso 7, Box 241523,

Bogotá, DC, Colombia.

Website: http://www.flar.net

Email:info@flar.net

Executive President: José Darío Uribe (Colombia).

\section{Organisation of Eastern Caribbean States (OECS)}

Founded in 1981 when seven eastern Caribbean states signed the Treaty of Basseterre agreeing to co-operate with each other to promote unity and solidarity among the members.

Members. Antigua and Barbuda, Dominica, Grenada, Montserrat, St Kitts and Nevis, St Lucia, St Vincent and the Grenadines. Anguilla, the British Virgin Islands and Martinique have associate membership.

Functions. As set out in the Treaty of Basseterre: to promote cooperation among the member states and to defend their sovereignty and independence; to assist member states in the realization of their obligations and responsibilities to the international community with due regard to the role of international law as a standard of conduct in their relationships; to assist member states in the realization of their obligations and responsibilities to the international community with due regard to the role of international issues; to establish and maintain, where possible, arrangements for joint overseas representation and common services; to pursue these through its respective institutions by discussion of questions of common concern and by agreement on common action.

The Authority is the highest decision-making body of the OECS, comprising the heads of government of the member countries. The OECS is administered by a Central Secretariat (based in Castries, St Lucia), headed by a director general who is responsible to the Authority. The Secretariat is divided into four principal divisions: the division of the office of the director general; social and sustainable development division; corporate services division; and economic affairs division.

In June 2010 a Revised Treaty of Basseterre was signed. It came into effect in Jan. 2011, establishing the OECS Economic Union. Under its terms, member states agreed to the removal of trade barriers, the free movement of labour and capital, the establishment of a regional assembly of parliamentarians and the implementation of a common external tariff. Membership of the Economic Union initially comprised Antigua and Barbuda, Dominica, Grenada, St Kitts and Nevis, St Lucia, and St Vincent and the Grenadines.

Official language: English.

Headquarters: Morne Fortune, PO Box 179, Castries, St Lucia.

Website: http://www.oecs.org

Email: oecss@oecs.org

Director-General: Dr Didacus Jules (St Lucia).

\section{Organization of American States (OAS)}

Origin. On 14 April 1890 representatives of the American republics, meeting in Washington at the First International Conference of American States, established an International Union of American Republics and, as its central office, a Commercial Bureau of American Republics, which later became the PanAmerican Union. This international organization's object was to foster mutual understanding and co-operation among the nations of the western hemisphere. This led to the adoption on 30 April 1948 by the Ninth International Conference of American States, at Bogotá, Colombia, of the Charter of the Organization of American States. This co-ordinated the work of all the former independent official entities in the inter-American system and defined their mutual relationships. The Charter of 1948 was subsequently amended by the Protocol of Buenos Aires (1967) and the Protocol of Cartagena de Indias (1985).

Members. Antigua and Barbuda, Argentina, The Bahamas, Barbados, Belize, Bolivia, Brazil, Canada, Chile, Colombia, Costa Rica, Cuba (suspended 1962*), Dominica, Dominican Republic, Ecuador, El Salvador, Grenada, Guatemala, Guyana, Haiti, Honduras, Jamaica, Mexico, Nicaragua, Panama, Paraguay, Peru, St Kitts and Nevis, St Lucia, St Vincent and the Grenadines, Suriname, Trinidad and Tobago, USA, Uruguay, Venezuela. ${ }^{\star}$ In June 2009 the OAS voted to lift Cuba's suspension, although Cuba had stated that it did not wish to rejoin the organization.

Permanent Observers. Albania, Algeria, Angola, Armenia, Austria, Azerbaijan, Belgium, Benin, Bosnia and Herzegovina, Bulgaria, China, Croatia, Cyprus, Czech Republic, Denmark, Egypt, Equatorial Guinea, Estonia, EU, Finland, France, Georgia, Germany, Ghana, Greece, Holy See, Hungary, Iceland, India, Ireland, Israel, Italy, Japan, Kazakhstan, South Korea, Latvia, Lebanon, Liechtenstein, Lithuania, Luxembourg, Macedonia, Malta, Monaco, Montenegro, Morocco, the Netherlands, Nigeria, Norway, Pakistan, Philippines, Poland, Portugal, Qatar, Romania, Russia, Saudi Arabia, Serbia, Slovakia, Slovenia, Spain, Sri Lanka, Sweden, Switzerland, Thailand, Tunisia, Turkey, Ukraine, UK, Vanuatu, Yemen.

Aims and Activities. To strengthen the peace and security of the continent; promote and consolidate representative democracy; promote by co-operative action economic, social and cultural development; and achieve an effective limitation of conventional weapons. 